\title{
Politics of Godfatherism and its Implication on Socio-Economic and Political Development of Nigeria
}

\author{
Fatima Ahmed \\ Department of Political Science \\ University of Maiduguri \\ Borno State. Nigeria \\ Email: fahtimadalaram@gmail.com \\ Mustapha Alhaji Ali \\ Department of Political Science and Administration \\ Yobe State University \\ Damaturu. Nigeria \\ Email: mustaphaalhajiali2@gmail.com
}

\begin{abstract}
In contemporary democracy politics of godfatherism has become a universal issue in the political development of many countries Nigeria inclusive. The paper studied the implication of politics of godfatherism on the socioeconomic and political development of Nigeria. Certainly, the politics of godfatherism have entered every hook and crannies of the nation and have affected the political structure of the country. This paper is qualitative in nature; data were obtained from secondary sources where numerous articles, newspapers, magazines, books reports, and archives were systematically reviewed. In elucidating the topic under examination, the researcher used Elite theory. This theory was advocated by Vilfredo Pareto in 1935, the postulation of the theory is that elites are replaced by another group of elites, meaning that the majority are unavoidably governed by the minority. The study found that the politics of godfatherism has a negative impact on the socio-economic and political development of the nation by confining power in the hands of the few elites at the expense of the masses (electorates). This has affected the socioeconomic and political development of the nation, and by extension led to inter-party and intra-party defections, decamping's and conflicts among the party members. Therefore, the study recommends the implementation of the direct primary election in the selecting candidate into elective positions. In addition to that, INEC should make a law that will discourage money politics and should as well punish the culprit involved in such an illegal political act.
\end{abstract}

Keywords: Development; God-Fatherism; Implication; Impacts; Nigeria; Political; Politics; Socio-Economic

\section{Introduction}

In Africa and other developing countries like Nigeria, godfatherism has become the central point of political vandalism this is as a result of the overconcentration of authority and capital of politicians explains the ascent for the control of the structures and organizations by the political class in the nation, this struggle, and the resulting values have obstructed significantly on society in a various ways (Ohiole \& Ojo, 2016:1).

Politics of godfatherism and regionalism has featured prominently in the political history of independent Nigeria. The problems arising from godfatherism are myriad and it is one of the greatest glitches facing the Nigerian political system. The problem is such that the god-son oftentimes is a stooge of the godfather "and he that pays the piper dictates the tune (Edigin, 2010:174)". The failure of the god-son to meet the demands of the god-father is often punished with impeachments or denial of re-election. He also observed that with the return to democratic rule in 1999 , the country witnessed a heightened tempo in the politics of godfatherism, which has affected the socioeconomic and political development of the country.

A study by Ohiole \& Ojo (2016:11), disclosed that democracy in Nigeria has not been fully established and the phenomenon of godfatherism has endangered democratic process and the socio-economic lives of the citizenry. Political godfathers is a condition in Nigerian political process influencing against the democratic establishment in order to satisfy their selfish interest they are even ready to manipulate the democratic body and its mode of operations, by overpowering public office holders like the governor and council chairman to dance to their tone. The 
activities of these political fighters have deprived the people of voting for their ideal applicants as their leader. This has directly affected the political arrangement and the national economy of the nation.

However, Nigeria with a projected population of 196,651,048 and one of the largest nation in Africa blessed with human and material resources, is by far the most populated nation in Africa (Ali, Zakuan, and Ahmad, 2018 \& UNDESA, 2018). It has three tiers of government structure these include federal, state, and local government. With six geopolitical zones across the nation. Nigeria comprises 36 states and Abuja. It also has 774 local government, and federal capital territory (Ahmed \& Shehu, 2014). With all these features yet Nigeria is characterizing with politics of godfatherism since independence this is as a result of the majority and minority domination and poverty that was artificially created by the politicians among the citizens to subjugate them to lower class. Political godfatherism in its simplest form can be generally seen as a practice which involves the sustenance of a kind of social and political relations in which the inferior looks onto the superior for the dissemination and self-actualization of firm roles, desires and connections which unite both together or in which both have equal pole but with the greater influence of what the inferior gets in the process (Majekodunmi, 2013:71).

Nigeria has all the below types of godfathers:

most especially those who serve others, those who expect the society to serve them, and even those who channel their resources into criminal activities. Our interest in this paper is on the politics of godfatherism in the democratic government (Albert, 2005:81).

Godfathers in some nations are inspired by their resolution to regulate public policies in favour of their concerns. For instance, in Nigeria, the primary motive of political godfathers is to control the treasury of the state. The godfathers in Nigerian politics are primarily concerned with appropriation of government contracts, political/public appointments and plundering the coffers of the state. They are in advantaged positions to decide the political confidence of candidates to political offices and as such those that are not only seen but confirmed to be "loyal" cannot be "given" ticket to be the flag bearer of the parties. This is to ensure that the godsons will be answerable to them when they were elected into power. Because of these conditions, some contenders defect to other parties where they do not have such influential figures that would aggravate them from their political ambitions (Okolie, 2006:171).

From the above expression, it is understood that democracy is a competition among the elite for control and entree to state power. However, it is contended here that in Nigeria the disaster of democracy can be traced to the failure of the political elite, as a class. Since 1954, there has been a fusion of the elite such that political elite also institutes both the economic and social elite. To be sure, the emergent political elite since 1954 have dominated the political territory to the exclusion of new candidates. The old elite has to controlled the political passage such that where they are not opposing for political positions, they desire to constitute themselves as the power behind the curtain, thereby, leading to the phenomenon of 'godfatherism'(Uadiale, 2012:94).

Looking at the above set-up it is understood that politics of Godfatherism has eaten deep into Nigerian politics this corresponds with the opinion of Plato, Aristotle, Tacitus, and other classical philosophers who largely centered on the concentration of political power in the hands of a few in the early Greek and Roman society. Thinkers such as Pareto, Mosca, Michels, and Marx too devoted their political analysis on how power is used and misused by the ruling class in diverse settings. The domination of power by the hegemonic class in many parts of the contemporary society can thus, be said to be nothing new but has a vigorous pedigree (Albert, 2005:79).

\subsection{Brief History of the Nigerian State and Democracy}

The Nigerian state was established because of the defeat and occupation of Lagos by the British between 1861 and 1914. In the year 1861 and 1914, all areas around the Niger River were progressively apprehended, some by power and others quietly give to British domination and rule. These areas which shaped the Nigerian state were before the conquest and occupation of Lagos, and the January 1914 unification were different nationalities, ethno-religious and geopolitical groups which were either separate or independent of one another or to a less extent inter-related to one another. With the 1914 unification, these areas from the Northern and Southern regions of the Niger River were amalgamated together and made as one political entity called (Nigeria). From 1914 to 1960 Nigeria remained under the British colonial rule which in addition brought party politics and the western styled parliamentary democracy into Nigeria over the years of colonial rule (Ali \& Isah, 2018:116).

In a related development a study by Isah and Ahmed (2018), disclosed that political activities in unified Nigeria began around 1922/23 when elections and a political party Nigerian National Democratic Party (NNDP) was recognized and conducted. This political movement and parties in Nigeria continued to develop up to 1960 when Nigeria attains its independence. The post-independence era also witnessed an increased number of political events 
as well as growing number of political parties and politically related groups and associations which had by January 1966 before the coup reached 81 (Mohammed, Aisha \& Saidu, 2018).

\subsection{The Advent of Politics of Godfatherism in Nigeria}

Politics of Godfatherism became widespread in Nigerian political movements in the 1960s, and early postindependence where leaders became political godfathers (Mamah, 2004). The action of political godfathers was obvious with the coming of civilian rule in 1979. However, the military governments that branded the 1980's jammed its achievement. Similarly, a study by Alabi \& Tunde (2013:6), pointed out that the political godfather phenomenon is not new in Nigeria politics. This circumstance started during the First Republic when the leading supporter of independence of Nigeria (Zik, Awo, Tafawa-Balewa, etc.) intolerant and managed political activities in Nigeria. However, there are lots of changes between the philosophical godfatherism of the First Republic and the unpolished form Citing (Gambo, 2007). Bernard drew the basis of godfatherism in electoral politics to the city of Chicago in the United States of America in the pre-world war II era, which he expressed that "when the heads of criminal gangs sponsored politicians in elections, manipulated the results to get them elected and, in turn, received protection and contracts from their political godsons (Bernard, 2009)".

Moreover, the 1999 civil rule attended another form of political godfatherism, which reached its ultimate during the unpleasant obliteration of lives and belongings that viewed the violent hostility between the political godfather (Chris Uba) and the then governor of Anambra state (Chris Ngige). This act leads to a new dimension to the exercise of political godfatherism in the Nigerian political movements where the godson dance the tone of the godfather in order to accomplish his or her political dream. This is contrary to the roles played by godfathers in Nigeria's democratic movements between 1958 and 1983 (Mamah, 2004).

\section{Problem Statement}

Politics of godfatherism has become part and parcel of the political condition of actualizing the political dreams of many contestants in Nigeria. Politics of godfatherism has eaten deep into the political movements of many nations Nigeria inclusive. Politics of godfatherism has affected the political and economic development of Nigeria. Several issues were observed as a cause of politics of Godfatherism. The central argument is that in the Nigerian politics "Godfatherism" has become the major problem to many candidates to win or fail in an election. Godfatherism is extensively practicing in all parts of the country, it is observed that to contest for any political post it has become necessary to have strong political godfather before considering and run for any elective offices or even political appointment. This is because many contenders cannot win an election without the support and influence of the godfather. So also, many individuals cannot get appointed without the support and influence of the godfathers that decide the faith of the state. But with the support and influence of godfathers, many aspirants contest and win the election. because of the power of the godfathers and incumbency.

The power, influence, and incumbency have created a serious problem between the contestants and the electorates, and by extension has affected the socio-economic development of the nation. This is because most of the candidates dance to the tone of their godfathers not the general populous. And it is the godfathers that are dictating the candidates what to do and not to do. This problem of the dictatorship of the political fathers has created a wide gap between the contestants and the electorates. It is understood that all the positions won or appointed because of the influence of godfathers cannot yield positive development. Because the political godfathers asked contestants or appointee to sign a treaty to ensure that they agree with all the promises that they had entered with the godfathers. However, (Gideons, 2010; Ohiole \& Ojo, 2016:2) noted that the contestant makes sure that all the money spends on he/she during the election were paid fully with interests. This led to a political crisis between the aspirants and the godfathers, by extension between the citizens in the states. This political crisis has created a wide vacuum between the godsons and the godfather. Based on this, the paper merit to examine the impacts of politics of godfatherism on the socio-economic and political development of Nigeria.

\section{Objectives of the Research}

- To examine the implication of political godfathers on the socio-economic development of Nigeria.

- To investigate the relationship between godfathers and godsons in political movements in Nigeria.

- To proffer solutions to identified problems

\section{Research Methodology}

This paper is qualitative; here the researcher used a secondary source in obtaining appropriate and interrelated literature. Here several documents such as books, articles, magazines, and newspapers were referred. All the relevant literature accessed were thoroughly studied and reviewed for the purpose of this study (Creswell, 2009; Zaleha, 2018). 


\subsection{Research Design}

Considering the nature of this study the researcher uses a case study approach in approaching the topic under examination. This is because the approach helps the researcher in understanding the phenomenon deeply. In addition to that, it also provides an in-depth understanding of a case or cases under inquiry. Case study approach helps in developing an in-depth explanation and examination of a case (s) (Creswell, 2009; Zaleha, 2018).

\section{Theoretical Framework}

In explaining this paper there are several theories that can support the study, but for the purpose of this research, the researcher adopted Elite theory to explained and supports the topic under investigation.

\subsection{Elite Theory}

The study used Elite theory in explaining the topic under examination. This theory was offered by Vilfredo Pareto in 1935 the supposition of the theory is that power is rotated among the elites, this means the elites are substituted by another group of elites, meaning that the masses are unavoidably ruled by the few elites at the expense of the masses (the electorates). It is understood that this idea was begun by Pareto and Mosca in 1935 the law of elite rotation, in line with the above assumption and to support the argument elite theory sees 'elites' as players governing the state and national resources, and occupying key positions related to power networks (Yamokoski and Dubrow, 2008). Thus, the perception of elites is more carefully connected to the Weberian knowledge of power, understood as the competence of executing one's will, even against the will of the general populous (Weber, 1922:696). However, it is understood that power can be accomplished through material and/or figurative resources. Subsequently, elites can simply be defined as those in control of capitals (Reis, 2005). This theory resided on how power is rotating among the elites in society. More so, the theory believes that power can only be shared among the elites at the expense of the masses.

\section{Literature and Conceptualization of Godfatherism}

Godfatherism is an impediment to Nigerian democracy. It is adversative to the freedom and welfare of the peoples. Therefore, the problem of godfatherism should then not be preserved as a party affair but should be treated with legal action by the government and the party stakeholders. To gain control over the state structure, politics of Godfatherism need to be tackle and control, this is because, with the politics of Godfatherism, godfathers often adopt different systems to outmaneuver their oppositions. Therefore, it is observed that in Nigeria, several approaches were used to win elections such as rigging, thuggery, violence, and manipulations of results in the interest of the godfathers (Wenibowei, 2011:72).

The term Godfatherism have been defined by several scholars based on their perception and understanding. In a study by Adeoye (2009:70-1), the term used to define the connection between a godfather and godson. A godfather is a kingmaker, boss, mentor, and principal, while godson is the beneficiary and recipient of the legacy of a godfather. A godfather is someone who has built unbelievable respect and follower (voters) in the community and possessed a well-organized political stand, and general acceptance from an electorate that could secure victory for candidates of his choice (Adeoye, 2009:72).

In a related view Jibrin Ibrahim defined the category of godfatherism, during an interview granted to the BBC on 10 November 2003 as "men who have the power personally to determine who gets nominated and who wins the election in a state'. For instance, Governor Chimaroke Nnamani of Enugu, who had a running battle with his godfather, Senator Jim Nwobo, for over two years, defined godfather from his own personal experience as follows: The 'political godfathers' in Nigeria build a collection of supporters around them and use their power, which is often tied to financial deliberations, to operate the rest of the society toward his or her interest. Political godfathers use their power and influence to block the involvement of the masses from Nigerian politics. The elite theory explained the above situation that power is rotating between the elites and subjugating the masses to subordinate positions. This signifies that the elites and the politicians are political porters: They decide who is to take part in the national politics and under what situations (Albert, 2005:80).

Politics of Godfatherism is one of the philosophies that open tinny doors when it comes to defining who gets what in the political division. Though, in the framework of this study, the literary meaning and characteristics of godfather need to be emphasized. Literarily, Godfathers in the Nigeria context refers to the men who have the power generally to regulate both who gets selected to the election race to wins the election (Alabi \& Tunde, 2013:5).

In another development, a study by Edigin (2010:175), describes or sees godfather as a human being who plays god to his people. He provides their basic needs for them, protects them and assists them to secure and achieve their objectives. He further states that "his support could be seen as an investment, which he believes must yield some profits in the near future".

Therefore, the demand for sustainable democracy in Nigeria is to expand both the political and socio-economic situation of the country through massive people participation in the policy and decision-making process, but contrary to Nigerian political system where those that reached political power in both arms of government 
Legislative and Executive were elected to power through the influence and support of some political 'godfathers' in many states. Nevertheless, the yearning of political godfathers is to hold political and socio-economic powers, both at the center and the local units as strategies to administratively influence the activities of political office holders. Such as the Governors and Legislators in terms of employing people into numerous posts, such as Ministers/Commissioners, Chairmen of the boards, Secretaries to the various Institutions, DPM and Treasurers of Local Governments as well as allocation of some developmental projects into various local government of interest across the state (Alabi \& Tunde, 2013:2-3). This is in line with the summation of Elite theory which buttressed that political power is shared among the political elites at the expense of the masses (electorates).

To explain the above assertions Albert (2005:81), noted that an important issue raised by Pareto and Marx in their works is that political elites insulate and isolate themselves from their society and try as much as possible to reproduce themselves from within. They do all possible within their reach to ensure that non-elites do not join their membership. This is in line with the postulation of the Elite theory, which believes that power is rotating among the elites by sidelining the masses to subordinate or to fallowers positions. To ensure this, the political elites maintain a safe, functional distance from the rest of society. They reproduce themselves on an individual and selective basis in a process which Pareto specifically referred to as the 'circulation of elites'.

In a related development, a study by Alabi \& Tunde (2013), disclosed that most Nigerian policies are usually determined by political godfathers to allow them to fix in their contenders to the corridor of power. In the recent time, Politics of Godfatherism has extended to upper, lower and state house of assembly, where all the contenders most have an influential godfather that would back him/her before winning an election. This signifies that political godfathers are the key to political success in Nigeria polity.

\section{Politics of Godfatherism in Nigeria}

Politics of godfatherism courses a lot of problems in the political movements of many states. These problems include intraparty and interparty conflict, party defection or party decamping. However, these conflicts arising from godfatherism has become one of the major problems affecting the political arrangement of many nations Nigeria inclusive.

For instance, politics of godfatherism become widespread in the Nigerian political system from 1999 to date, when those in power became the political godfathers in states politics. The deed of godfathers was noticeable in the state in 2007 when late governor Mamman B. Ali of the blessing memory came out to vie for the post of the governorship in the state, only a few politicians were in support of his intention to contest for the post. Most of the political leaders and the party stakeholders were not in his support. This is because he has no political godfather that will support him to vie for the post, but he keeps on struggling in actualizing his political dream to become the governor of the state in 2007. However, Late Senator M. B. Ali scored a major victory at the Supreme Court. The victory was in respect of a case brought by late Senator U. Al-Bashir disputing the replacement of his name with that of late Ali as an aspirant of the All Nigerian Peoples Party (ANPP) for the 2007 governorship election (Com, 2018).

In a similar opinion a study by Albert (2005:81), pointed out that: "men who have the power personally to determine who gets nominated who in the state". Governor Chimaroke Nnamani of Enugu, who had a running battle with his godfather, Senator Jim Nwobo, for over two years, defined godfather from his own personal experience as follows:

an impervious guardian figure who provided the lifeline and direction to the godson, perceived to live a life of total submission, subservience, and protection of the oracular personality located in the large, material frame of opulence, affluence and decisiveness, that is, if not ruthless ... strictly, the godfather is simply a self-seeking individual out there to use the government for his own purposes.

In line with the above assertion a study by Ohiole \& Ojo (2016:6), unveiled that the battle line in Oyo State was drawn between Lamidi ADEDIBU - the kingpin of Ibadan Politics (godfather) and the (godson) governor of the State, Rashidi LADOJA. Adedibu demanded to have donated financially in "installing" LADOJA as the state governor, with an arrangement that the governor will be faithful and obedient, taking orders from him and to subject public resources, to his private impulses and whims.

Nevertheless, LADOJA defaulted and declined to play according to the rules of the game. This led to confusion in Ibadan the state capital. After the 2003 general elections till January 2006. Because of this confusion, many lives and properties were lost. The State House of Assembly was also divided into two and this led to the suspension of fourteen (14) members out of thirty-two (32) - members State House of Assembly. Then, LADOJA was arraigned in less than 30 minutes in January 2006, this gave the opportunity for the deputy governor, Alao AKALA, another godfather who is willing to serve the godfather well. This position was sustained up to December $7^{\text {th }}, 2006$. It was 
after eleven-month Supreme Court ruled out the case in favour of the governor, that his removal was illegitimate, and he was returned after eleven (11) months out of his office. His coming back to the office was confronted with the grave fight from his former godfather's (ADEDIBU) camp, which led to break in law and order of the State capital for few days and living many blameless inhabitants with various kind of injuries (Azeez, 2014; Ohiole \& Ojo, 2016)

In a similar view Sale (2018), disclosed that same thing applies to Yobe North senatorial district where the ruling party has fielded the longest-serving senator in the state, Senator Ahmed Lawan, the current Senate leader. Political analysts in and around the state posited that Adamu Maina Waziri has contributed immensely in making PDP in Yobe State weak. They said since the inception of democratic rule in 1999, Waziri has been the sole gubernatorial flag bearer of the party and has never for once won election or allow somebody to make any move to contest. He is being accused of pocketing the party and tilting it to where it will serve his personal interest. Some party faithful in the state went to the extent of accusing him of working for the ruling APC. Presently, there are serious political crises between the present Senator and Waziri. Based on the political analysis if this internal party wrangling between A. Waziri and M. Hassan, if not amicably addressed before the coming general elections, it will no doubt lead to PDP losing the seat to APC, and if this happens, APC will be happy, because Zone B is the only Zone among the three senatorial Zones that is being represented by PDP (Sale, 2018). To minimized this problem of godfatherism the study suggested for the direct primary election in the country.

\section{Direct Primary Election}

In order to minimize the problems of godfatherism and uphold free fair and credible election in Nigeria the paper suggested for the proper adoption of direct primary election. This is in line with the declaration of APC National Chairman in 2018, and in preparation of 2019 general election. According to (Oladesu, 2018; Ojeifo, 2018) the APC national chairmen declare the implementation of direct primary elections in the APC across the 36 of the federation this is to overcome the problem of godson and godfather domination in the APC political movements. He believes this method of the direct primary election would help in electing the right aspirant for 2019 general elections. This idea arose in a leadership meeting with the party caucus in Abuja. Comrade Adams Oshiomhole-led National Executive Committee, he declared that all the contested would be elected through the direct primary election this is to ensure equality and justice to all contestants and to sustain free, fair and credible election. This decision was not in any way vague.

In line with the opinion of APC chairman, the president supported the implementation of the direct primary election for all APC candidates across the federation (Oladesu, 2018). The chairman clarified the acceptance of the direct primary election which would give all registered members of the party the chance to take part in the process of defining those to represent the right and interest of the party members at all level of governance. This basically describes the distinctive democratic style (Ojeifo, 2018).

The national chairman highlighted that:

We note that direct primary election is free from the vices associated with the indirect primary. Direct primary cannot be wrought. It is not disposed to corruption, we want to grow democracy. We want the party members to have ownership of the party. We want to give our members a sense of belonging (Oladesu, 2018:1-2).

The All Progressives Congress (APC) was requested to adopt the direct primary for the selection of its candidates for 2019 general elections to enhance inner democracy, the Chairman emphasized. He explained that he suggested for the implementation of the direct primary election in order to 'liberalize' its shadow polls by making all registered APC members automatic delegates. He added that this option will lessen the corruption and manipulation related to the delegates mode of selecting the contestants, which always causes huge post-primary violence and crises in the nation (Oladesu, 2018). To him, the implementation of a direct primary election helps in no small measure in minimizing the power of incumbency in the political movements of Nigeria. This would encourage the general populaces who are willing and interesting to participate and contest for any political position of their choice. This assertion is measured by Elites theory that power is rotating among the Elites at the expense of the electorates. To curtail the problem of godfatherism all the political parties should adopt and implement these policies of the direct primary election, this would help in sanitizing the election process at all level of government. It would as well lead to free fair and credible election by electing credible candidates in electives positions. Although, some states across the nation didn't adopt the direct primary election. This is because of power incumbency and interest to manipulate the political power to a certain geopolitical Zone that has been dominating the state politics for many years (Sale, 2018). Politics of Godfatherism has become part and parcel of Nigerian politics. Looking at the 
structure of the National and State House of Assembly it is noted that most of the members have dominated the position since 1999, some have inherited the post and sustain it for many years because of the influence and the power of Godfatherism that has denied the masses from contesting for the posts. This is the true picture of the Elite theory that believes in power circulation among the elite in society (Yamokoski and Dubrow, 2008).

\section{The Causes of Politics of GodFatherism in Nigeria}

The study found that there are numerous factors that lead to the politics of godfatherism in Nigeria. Among which are: the power of incumbency, influence, money, political thugs, money politics, lack of political awareness, selfishness, greediness, lack of exposure, over-ambition, nepotism, and politics of regionalism among others. There is an emerging tendency in Nigeria which labels that an anticipating contender must have and depend on the godfather with the necessary capital, influence, and power to get he/she voted and acquire power. The consequence is that participants are more depending on their acceptance from the electorates, but on their selected godfathers to support them secure elected positions (Aderonke, Awosika \& Olanrewaju, 2013:70).

In the same way, it is understood that corruptive tendencies intensify the economic base of the godfathers by making a wide diversity of difficulties in the politics and rule because the godfathers use their influence, capital to place their godsons and wards in several positions of power. So also those in power use their position to decide the next to represent the interest of the citizens at all cost (Oviasuyi, 2009:73)

A study by (Ohiole \& Ojo, 2016:4) noted that election sponsors are rich, powerful and influential individuals which come out freely to pay kindly towards the voting success of a party or sponsor candidates during an election. More so, Ohiole \& Ojo (2016), added that the political godfather might be less concerned about the active politics or organization of régime but thinks of approachable policies from the administration. "Nigeria's godfathers in the 21 st century sponsors election, but not all election sponsors are godfathers”. Though, Godfathers reign across all spheres of the society: academics, legal, and religious environment.

To support the above statement, Popoola, (2014:1-2), unveiled that political godfather and godson fight has been upsetting the nation socio-economic development. This fight rooted in the crash of interest, needs, values, and capitals, involved political office holders in the highest ladder of government. Which invariably affects the socioeconomic and political development of the nation.

\section{The Implication of Godfatherism}

Politics of godfatherism affects the national economic and political development in no small measure this is because the influence of the political godfather and the loyalty of the godson in the political movements. The study found that politics of godfatherism had so much inclined the political life and socio-economic development of the country and particularly in this present regime. It had added enough care at the present regime because of its need approaches of expression. It has become almost unbelievable for an individual to hold political power either by election or appointment without patronizing his/her political godfather because of their power and influence (Joe, 2010:1-2). In this case all the activities of the godson must be in line with the interest of the godfather, this is to sustain the political relationship of godfatherism.

A study by Chukwuma (2008:87), disclosed that the politics of godfatherism has a negative implication on the political arrangement of Nigeria and the citizens. Certainly, the right to select an aspirant of their choice to rule them is run-down given the conditions in which godfathers are the deciders of who is to contest or imposed candidates of their desire on the general individuals in the society. This is, to say the smallest and actual aggression to the faiths of democratic rule.

Politics of godfathers in the Nigerian states are not simple sponsors of political campaigns, rather they are people whose influence stems not just from wealth but from their capacity to organize violence and corruption to manipulate central, state or local political schemes in support of the candidates they champion. A study by Oluloyo (2014:3), observed that godfather request a considerable grade of control over the government not in order to support or form government policy, but to extract direct financial return in the form of government resources stolen by their politicians or gave to them as further opportunities for the implant. The over-concentration of influence, wealth and power of politicians describes the ascent for the regulating of the political structures and institutions by the ruling class in society. However, the struggle and the resulting standards have impacted significantly on society in various way. In the present emerging democratic practice, the power struggles among the members of the ruling class have given rise to violence in different forms and digress. In a related opinion study by Ohiole \& Ojo (2016:10-11), revealed that Nigeria politics has been characterized by godfatherism, religious and tribal politics, money-bag politics, regionalism, and party politics.

Ohiole \& Ojo (2016:11), added that political godfatherism is based on political substitution relating to financial and moral aid where the godfather is the main donor and the godson the primary receiver, as a result, the common people are being destabilized with no dividend of democracy. Meanwhile, Godfather has endangered the existence 
of Nigeria nascent democratic practice. For instance, the illegal removal of Oyo State Governor Ladoja in 2006 lead to political uncertainty in the state.

In a related development Oviasuyi (2009:74), showcased that there has been a lot of calamities in Nigerian politics and Administrative crisis of self-assurance in the chosen legislatures, a loss of faith in the democratic rule and a rising deterrent at government, also, a rising frustration at the insignificance individual's vote in the political development. All these catastrophes are disasters prompted by the unholy association of godfatherism, that believe in the power of incumbency and influence in the nation.

According to (Aderonke, Awosika, \& Olanrewaju, 2013:71) politics of Godfatherism is not a new phenomenon in the political movements of Nigeria. It has only assumed a new system, under the present republic of democratic governance.Partly because the Nigerian economy is at the primitive stage of wealth accumulation by the politicians and commissioned representatives with little or no productive capacities. In Nigeria, it is thought that politics is the only way of achieving state resources.

However, it is understood that politics of Godfatherism and politics of godson has become the prevailing feature explaining the modern politics in Nigeria. The role of a political miracle has impacted on the body politics of the state virtues which are now a possible menace to the state democracy and democratic development (Aderonke, Awosika, \& Olanrewaju, 2013:71). Nigeria joined the comity of democratically governed countries, it has continued to experience an unmatched rise in political wildness ranging from an increases crime tendency, political killing, armed robbery, and religious riots because of the crisis that arose between godfather and godson (Ohiole \& Ojo, 2016:2). This crisis has affected the socio-economic and political development of the country.

For instance, a study by Ukhun (2004:16) unveiled that most of the contestant work with the godfather's instructions, they cannot execute any important project without the opinion of the godfathers. This affects the socioeconomic development of the state. For example, if the godfathers sponsor a candidate into an elective position, such as governor, or president, then he has the power and right to recommend for the post of commissioners or ministers for a political position into the cabinet and to request for exaggerated contracts, and if he refuse to comply with the godfathers request than problem would emerge.

The present trend of politics of godfatherism is not only a threat to Nigerian political culture, orientation and socialization, but also to the Nigerian legal system since there are glaring abuses, confusion, manipulation and widening gap in the constitutional interpretation and adherence with provisions of the political parties among Nigerian politician, particularly the legislators at the federal and states levels, who have now established a political market for politics of godfatherism based on personal interests hinged on flimsy political excuses (Ali \& Isah, 2018:129).

The coming of godfatherism demonstrated a great peril not only to good governance but also to the socio-economic development and firmness democratic rules. Feasibly, one of the most alarming and destructive effects of godfatherism in Nigeria's fourth republic is the area of making nonsense of a truly free, fair and credible electoral process in which the voters by right are anticipated to freely elect people of their choice into public office to represent their right and interests (Nkwede, Ibeogu, \& Nwankwo, 2014).

\section{Findings}

From the available literature reviewed, the study found that the truth is that most honest, accountable and dedicated political aspirants in Nigeria are not financially buoyant they are not influential and did not possess the financial capacity to compete and win in the primary election and proceed in the general election. A study by Adeoye (2009), noted that most of the party aspirants are hiding under the canopy of political godfathers in order to win the election. Though the introduction of money-politics into Nigeria political system gave birth to the politics of godfatherism, since then the politics of godfatherism became very strong and effective in influencing the political arrangement of the nation. Because of this, the relationship between the godfather and the godson is based on political agreement (reciprocal relationship). Because this mutual agreement and reciprocal relationship most of the political godfathers are ready and willing to sponsor a candidate that will dance to their tone by fulfilling all the agreement? This finding is in line with the statement of the Elite theory which beliefs in power control within a certain group of people. In view of this, those contenders that are desperate for power had to pledge cooperation of the political godfather for a definite delightful ticket or else they would not have the ticket to contest for any political post (Adeoye, 2009:270). According to (Aderonke Awosika, \& Olanrewaju, 2013:74). Politics of Godfatherism and political struggle have become the central attribute portraying Nigerian politics these days.

In line with the above finding, a study by Olarinmoye (2008:69) revealed that:

One thing with politics is that you must believe in godfatherism. If you did not believe in it, you would not be in daddy's place," Reverend Jolly Nyame, the governor of the Taraba State, told Nigeria's The Sun newspaper. He then added that "Whether you like it or not, as 
a godfather you will not be a governor, you will not be a president, but you can make a governor, you can make a president." "I am the greatest godfather in Nigeria because this is the first time an individual single-handedly put in position every politician in the state.

Based on the above finding Coker (2004), mourned that "godfathers of Nigeria politics have always used their influence, power, positions, and resources for their personal gain to the disadvantage of the poor masses (electorates) to influence the political arrangement in the favour of their aspirants.

The study further found that the politics of godfatherism leads to intra and inter-party defections among politicians. It is clear in all the intra-party conflicts and inter-party defections in Nigeria are not limited a single politician has shown an express concern about the current security challenges and provision of social amenities in his or her constituency, local, state, and or the federation. This depicts the politicians' primary concern and interest in electoral victory, continued political accommodation and relevance, and control over public resources (Ali \& Isah, 2018).

The study also found that the nature of establishing and operations and character of the Nigerian political parties is generally not strong, disjointed, non- ideological and twisted towards only winning the election at all cost and gain control of political and economic powers of the state. This is mostly accomplished through the influence of godfathers at the expense of the citizens. And, at the expense of other strategic functions of political parties in a stable and enduring democratic situation. The Nigerian political parties are neither strong nor ideological in content and character. Any political and party system without strong and ideological political parties can hardly achieve the objectives of democracy (Okonkwo \& Unaji, 2016;Ali \& Isah, 2018:128).

\section{Recommendations}

To minimize the effect of politics of godfatherism on Nigerian socio-economic development. The study made the following recommendations as recognized by (Bernard, 2009). He suggested that these factors must be considered to shorten these unlawful political acts (as cited in Alabi \& Tunde, 2013:19):

- All political godfatherism should be cast off and strengthened democratic institution to avoid politics of godfatherism of central government policies and programmes in order to inform the citizens on the significance of contributing in the election, and citizen consciousness should arise on demanding a good response from the ruling class.

- The study recommended that all political parties should accept the principles of direct primary elections at all level of governance, this would give room for every interested inhabitant to contest and participate in politics.

- There is a need for massive political enlightenment campaigns to educate the general populous on the negative effect of political godfatherism on the political development of the nation. This will help in minimizing the problems of political godfathers.

- Independent National Electoral Commission (INEC) should accept the use of electronic voting for all elections in the nation to limit electoral cheat this will reduce the elections rigging and will as well encourages the interested candidates to vie for any position of his or her choice.

- There is a need for increased confidence in the duly elected officials and increase faith in the democratization process.

- The impression of paying a large amount as allowances and salaries to elected political leaders should be stopped, this is to discourage the godfathers and those politicians that are contesting for money sake. This will make all elective positions in the Nigeria context unattractive.

- To avoid confusion and misleading of the electorates or the voters, all political parties should positively stipulate time and venues for the primary election.

- It is, therefore, suggested that godfatherism should not be treated as a party affair, but should be offered political, social and legal treatment by the government and the stakeholders in the state.

- Electorates should be allowed to vote for the preferred candidates during elections without pressure by political monsters who are part of the devices of godfatherism.

- Power of incumbency should be controlled by employing provisional government in place of incumbent President, Governor and Local Government Chairmen shortly before the beginning of the next elections campaign. This will limit the practice whereby the public office holders oversee over the elections in which they are contesting and collaborate with godfathers to rig the election outcomes.

- All political party should make the price of nomination forms affordable, this would create an avenue for the masses to contest in their various constituencies, local government, state as well as the federal level.

- The electoral law should lay stress on appropriate conduct of primary elections into various positions to improve the rights of the voters in the choice of their aspirants or representatives. 


\section{Conclusion}

This paper concluded that the politics of Godfatherism has affected the socio-economic development of Nigeria. However, it is obvious that the politics of godfatherism is not a new phenomenon in the history of Nigerian democracy. The study noted that politics of godfatherism is affecting the socio-economic development of the nation negatively, by influencing the elections result in the favour of their contenders that would dance to their tune after the election by awarding them with contract and appointment to give to their friends and relatives at the expense of the masses (electorates). The effects of godfatherism are visible and featuring on the people face. This has changed into a hydra-headed monster as observed by Aderonke, Awosika, \& Olanrewaju (2013:74), which explained that if nothing is done on the politics of godfatherism in this nation can shorten the hard-gotten democracy. The study further expressed that Nigerian politics characterize with these types of godfathers: Most especially those who serve others, those who expect the society to serve them, and even those who channel their resources into criminal activities. The paper completed that politics of godfatherism has become a social phenomenon that has entered the hook and crannies of every state and has dominated the political settings of the nation. This paper concludes by knowing the inevitability of godfathers in politics but there is a need for appropriate supervision of godfather/godson relationship.

\section{References}

Adamu S. (2018). 2019: Battle Between Unequal Actors In Yobe. Leadership, pp. 1-3.

Adeoye, O. A. (2009). Godfatherism and the future of Nigerian Democracy. African Journal of Political Science and International Relation, 3(6), 268-272.

Adeoye, O. A. (2009). Godfatherism and the future of Nigerian democracy. African Journal of Political Science and International Relations, 3(6), 268-272.

Ahmed, M., \& Shehu, M. I. (2014). Democracy and Its Adoption in Nigeria: Western Liberal or Indigenous Option, $5,63-68$.

Alabi, A \& Tunde, R. S. (2013). Democracy and Politics of Godfatherism in Nigeria: International Journal of Politics and Governance, 4(4), 1-21.

Albert, I. O. (2005). Explaining' godfatherism' in Nigerian. African Sociological Review, 9(2), 79-105.

Ali, A. M., Zakuan, A. A. U. A., \& Mohammad, B. Z. (2018). Northern Nigerian Women Participation in Trade Union Movement: Impediments and Solutions. Journal of Humanities and Cultures Studies R\&D, 4. Retrieved from https://www.jsrd-humanities.com

Ali, M. A. and Isah S. M. (2018). Politics of Inter-Party Defections in Nigeria: Who's Interest? African Journal of Management, 3(4), 114-135.

Azeez, K. (2014). Electoral violence and Nigeria's. Journal of African Election, 6(2), 112-121.

Bernard, O. D. (2009). Godfatherism in Nigerian Politics and the Impact on National Development, Lagos: Centre for Management Development, Shangisha.

Chukwuma, O. (2008). Political Godfatherism in Nigeria: Benevolent or Malevolent Factors. International Journal of Social and Policy Issues., 5(2), 86-93.

Coker, K. O. (2004). “Christianity and Godfatherism; Lessons For Nigerian Politicians”, Daily Independent, January 16.

Edigin, L. U. (2010). Political conflicts and godfatherism in Nigeria: a focus on the fourth republic. An International Multi-Disciplinary Journal, Ethiopia, 4(17), 174-186. https://doi.org/10.1002/aic.11132

Emmanuel O. (2018). Why APC Opted For Direct Primary, By Oshiomhole. The Nationtion Newspaper, pp. 1-3.

Gambo, A. (2007). "Godfatherism and Electoral Politics in Nigeria", (ed).

Gideons, A. A. (2010). The Political Economy \& Development in Africa, Makurdi: Destiny Ventures.

Isah S.M. and Aisha A.A. (2018). Nigerian Political Development.

Joe Project Store. (2010). The Influence of Godfatherism In Nigeria Politics in The Fourth Republic (The Role Of Education).

John W. C. (2009). Research Design: Qualitative, Quantitative, and Mixed Methods Approaches.

Majekodunmi, A. (2013). Godfatherism and Political Conflicts in Nigeria: The Fourth Republic in Perspective. International Journal of Management and Social Sciences Research, 2(7), 70-75.

Mamah E. (2004). First Generation Politician Started Godfatherism', August 27, 2004; http://www.vanguardngr.com/articles, accessed on May 30, 2007. Vanguard, 1-27.

Mohammed, I. S., Aisha, A. A., \& Saidu, A. (2018). Nigerian political development. Beau Bassin, Mauritius: Lambert Academic Publishing. Mosca.

Nkwede, J. O., Ibeogu, A. S., \& Nwankwo, O. U. (2014). Political Godfatherism and Governance in a Developing Democracy: Insight from Nigeria. Academic Journal of Interdisciplinary Studies, 3(4), 137144. https://doi.org/10.5901/ajis.2014.v3n4p137 
Ohiole, K., \& Ojo, S. (2016). Political Godfatherism and Democratic Consolidation in Nigeria: Empirical Evidence From Oyo State and Kwara State. Arabian Journal of Business and Management Review, 5(8), 112.

Ojeifo, S. (2018). APC and the Beauty of Direct Primary Election. Vanguard.

Okolie, A. M. (2006). Prebendal Politics and Democratic Practices in Nigeria, 1999-2004. ANSU. Journal of Politics and Administration, 1(1).

Okonkwo, C. N., \& Unaji, F. N. (2016). Intra-Party Conflict And Prospects Of Democratic Consolidation In Nigeria. IOSR Journal Of Humanities And Social Science, 21(5), 91-98. https://doi.org/10.9790/08372105039198

Oluloyo, V. (2014). The Politics of godfatherism in Nigeria, the past, present, and the future. Journal of Politics and Development, 9(1), 6-15.

Omobolaji O. O. (2008). Godfathers, political parties and electoral corruption in Nigeria. African Journal of Political Science and International Relations Vol., 2(4), 066-073.

Oviasuyi, P. O. (2009). Impact of Godfatherism on Nigerian Politics and Administration: Anambra and Oyo States Experiences. Educational Research Quarterly, 33(2), 73-87.

Pareto V. (1935). The Mind and Society. London: Jonathan Cape Limited.

Popoola, M. (2014). Political Godfather-Son Conflict in South-Western Nigeria, 2004-2006: The Role of the Press Mass Communication \& Journalism. Mass Communication \& Journalism, 4(7), 1-11. https://doi.org/10.412/2165-7912.1000205

Reis E. (2005). Perceptions of poverty and inequality among Brazilian elites. In Reis E and Moore M (eds) Elite Perceptions of Poverty and Inequality: London: Zed Books, (pp. 26-57).

This Day. (2018). Yobe Guber:Mamman B. Ali wins in Death.

Uadiale, M. (2012). The implication of the Political and Economic factors in the rise of "Boko Haram " Insurgency in Nigeria, 3(3), 81-100.

Ukhun, E. C. (2004). "Godfatherism, The Scourge of Democracy in Nigeria". Essence Interdisciplinary International Journal, 1.

UNDESA. (2018). United Nations Department of Economic and Social Affairs: Population Division; Countrymeters.

Weber M. (1922). Economia y sociedad. Mexico DF: Fondo de Cultura Económica, 696.

Wenibowei, K. M. C. (2011). Political Godfatherism, Violence and Sustainable Democracy in Nigeria. International Journal of Advanced Legal Studies Governance., 2(1), 113-125.

Yamokoski A and Dubrow JK. (2008). How do elites define influence? Personality and respect as sources of social power. Sociological Focus, 41(4), 319-36.

Zalihah O. (2018). Important things about Qualitative Research.

\section{Copyrights}

Copyright for this article is retained by the author(s), with first publication rights granted to the journal.

This is an open-access article distributed under the terms and conditions of the Creative Commons Attribution license (http://creativecommons.org/licenses/by/4.0/) 